\title{
$>$ A escuta do amor, de orelha a orelha
}

$>$ The listening of love, from ear to ear

\section{por Lucas Cyrino}

Doutorando em Letras/Estudos de Literatura na linha de pesquisa Literatura, Sociedade e História da Literatura do Programa de Pós-Graduação em Letras da Universidade Federal do Rio Grande do Sul (UFRGS), com bolsa Capes. E-mail: laccyrino@gmail.com. ORCID: 0000-0001-5328-2396.

\section{Resumo}

Este ensaio propõe uma análise multissensorial a partir das representações do amor como tema central da poesia, observados na obra Escuta (2015), do poe-ta carioca Eucanaã Ferraz. Tomando por base a fenomenologia de Merleau-Ponty sistematizada por Alckmar Luiz dos Santos (2016), procuramos observar que os caminhos por onde o amor se desdobra nas superfícies dos poemas vão desde o ser amado até a própria poesia, incidindo sempre na escuta pro-funda dos sentimentos e na representação das sensações relacionadas aos cinco sentidos humanos.

Palavras-chave: Amor. Poesia. Escuta. Sentidos. Eucanaã Ferraz.

\section{Abstract}

This essay proposes a multisensorial analysis based on the representations of love as the central theme of poetry, observed in Escuta (2015), by the carioca poet Eucanaã Ferraz. Based on Merleau-Ponty's phenomenology systema-tized by Alckmar Luiz dos Santos (2016), we intend to observe that the ways in which love unfolds on the surfaces of poems range from the loved one to poet-ry itself, always focusing on a profound listening of feelings and on the repre-sentation of sensations related to the five human senses.

Keywords: Love. Poetry. Listening. Senses. Eucanaã Ferraz. 
"Tiremos de entre nós essa palavra pois lembra que antes de a pronunciarmos os nosso dias eram mais suaves"

Eucanaã Ferraz, Escuta, 2015, p. 109

Eucanaã Ferraz desponta, já há algum tempo, como um dos grandes poetas da literatura brasileira contemporânea. Sua obra artística teve início com Livro Primeiro, coletânea de poemas publicada em 1990 pela CIP-Brasil; mas foi somente em 2002, com a publicação de Desassombro (7 Letras), que o reconhecimento começou a bater à sua porta: com essa obra, Eucanaã venceu o Prêmio Alphonsus de Guimaraens da Fundação Biblioteca Nacional. Outros prêmios vieram corroborar a genialidade de sua poética: com as obras subsequentes, o poeta venceu, em 2008, por Cinemateca (Companhia das Letras), o Prêmio Jabuti de Poesia, e em 2013 a obra Sentimental (Companhia das Letras, 2012) lhe rendeu o Prêmio Portugal Telecom de Poesia. O envolvimento com a arte poética acompanha sua formação profissional e acadêmica: professor de Literatura Brasileira na UFRJ, Eucanaã Ferraz apresentou sua dissertação de mestrado, em 1992, sobre Carlos Drummond de Andrade, e defendeu a tese de doutorado, em 1997, a partir da poética de João Cabral de Melo Neto. Alinhado ao estudo desses grandes mestres, ele ainda é pesquisador da obra de Vinicius de Moraes e de Caetano Veloso, tendo publicado diversos estudos sobre ambos. Escuta (Companhia das Letras, 2015) já não é seu livro de poemas mais recente (posição ocupada por Retratos com erro, publicado em 2019 pela Companhia das Letras), mas é a ele que nos dedicaremos neste ensaio.

Escuta é uma obra cujos poemas percorrem diversas paisagens urbanas, como bem destaca a crítica literária; ${ }^{1}$ mas que tratam, nesse entremeio, dos instantes, dos fragmentos do mundo mais comuns e ao mesmo tempo mais inerentes às relações da vida cotidiana. No retrato, na fala ou na escuta dessas situações, espalhadas pelo globo e ao mesmo tempo sem endereço, a voz do eu

\footnotetext{
${ }^{1}$ Cf. Tarso de Melo, Com versos densos, Eucanaã perturba e diverte em Escuta, 2015. E André di Bernardi Batista Mendes, Vozes do mundo, 2015.
} 
poético vai do trivial à profundidade (e por vezes incompreensão) dos sentimentos humanos para abordar, principalmente, a morte, o amor, a violência, a ausência, a morte do amor e a própria poesia. João Felipe Gremski, em sua dissertação de mestrado a respeito de uma poética de Eucanaã Ferraz, trata de Escuta ao afirmar que nessa obra "a defesa de uma arte mais convencional e trivial reside não na banalização dos temas discutidos, mas em um foco maior em personagens e situações banais para, assim, poder falar do elevado"2.

Se levarmos em conta que o trabalho do poeta também é fruto da sua experiência como leitor, e observando que a vida de Eucanaã é preenchida pela poesia a partir de seus estudos sobre Drummond e João Cabral de Melo Neto (a incluir, ainda, Vinicius de Moraes), não será preciso ir longe para reconhecer ecos desses poetas na sua obra. Sua poética de fato ecoa, por meio do eu que se desenvolve ao longo de Escuta, a "inquietude drummondiana de olhar para o 'eu' e para o mundo, não achando conforto em nenhuma dessas duas perspectivas"3. Dessa inquietação vamos destacar, neste ensaio, o desconforto que o eu poético encontra ao se deparar principalmente com o amor, atravessado por seus momentos de alegria e de desilusão.

\section{A escuta e os sentidos nos sentidos da escuta}

São vários os jogos de ambiguidade que o eu poético coloca ao leitor no decorrer dos poemas. O primeiro deles, provavelmente um dos mais importantes para o todo da obra, talvez passe despercebido à primeira leitura e só faça sentido quando observados os poemas como um conjunto: o título, Escuta. Essa escuta pode se referir, à primeira vista, a um substantivo: como abstrato, pode remeter ao ato de escutar, à ação própria da audição; como próprio, pode se referir ao lugar de onde se pode escutar, como um posto de escuta, comum à atividade militar. Pode, ainda, ser o nome de uma peça investigativa, colocada em um ponto

\footnotetext{
2 João Felipe Gremski, Um estudo da obra poética de Eucanaã Ferraz, 2016, p. 132.

${ }^{3}$ Ibidem, p. 130.
} 
estratégico para a detecção proposital de alguma atividade da qual possivelmente se desconfie. Pode, também, ser verbo, indicando, mais do que o ato, a própria ação de escutar. Na terceira pessoa do singular do presente do indicativo, o verbo refere-se a alguém - ele ou ela - que escuta alguma coisa; na segunda pessoa do singular do imperativo afirmativo, o verbo trata de uma ordem. É como se o livro, por exemplo, mascarando a voz do seu eu poético, dissesse (ou melhor, ordenasse), em meio ao redemoinho de informações que caracteriza a vida contemporânea: tu, aí distraído, escuta o que dizem estes poemas!. A todas essas acepções, no entanto, relaciona-se uma porção sensorial inerente à atividade humana, por meio da qual, seja pelas formas do substantivo ou pelas formas verbais, faz-se necessário escutar, faz-se necessário ouvir: o título remete, obviamente, à audição.

A aproximação sensorial dessa obra vai além: antes ainda de alcançar a superfície dos poemas, esbarra na sua estrutura organizacional. Divididos em três grandes seções (Ruim, Alegria e Memórias póstumas), os textos são guardados por quatro poemas, que também se dividem, em pares, naquilo que são chamadas Orelhas - motivo de mais um jogo de ambiguidade. Do ponto de vista estético da obra literária impressa, esses poemas podem ser imediatamente relacionados às orelhas de livros que, integradas à capa, geralmente trazem informações sobre o conteúdo e seu autor. Os poemas das Orelhas de Escuta talvez cumpram um pouco desse papel, mas podem ir além. Na anatomia humana, as orelhas são a parte externa do sistema auditivo que primeiro protegem a audição: elas são acompanhadas, ainda, do ouvido, parte mais interna à qual se condiciona não somente a audição, mas também o equilíbrio (aquele físico-motor, que permite que caminhemos sobre duas pernas). Escuta e equilíbrio ficam guardados entre as orelhas, mas não apenas: grosseira, porém legitimamente, entre as duas orelhas e dentro do crânio fica acondicionado o cérebro, motor de todos os pensamentos e ações realizados pelo corpo, no corpo e por seu proprietário; além de todas as funções às quais se vinculam, por meio do sistema nervoso central, os demais sentidos além da audição - às vezes movidos por órgãos não tão próximos 
como as orelhas: o paladar e o tato, por exemplo. Em exercício mais grosseiro, se analisarmos a imagem de um rosto humano e traçarmos uma reta entre ambas as orelhas, geralmente essa reta irá trespassar pelo menos outros dois sentidos: a visão e o olfato.

Analogamente, é como se a Escuta de Eucanaã Ferraz propusesse ou pedisse que o leitor escute o que dizem os poemas; porém, entrecortados pelos demais sentidos, notadamente presentes (ou guardados) entre suas orelhas (ou seja, entre seus poemas), a obra pede que se sinta o que a poesia tem a dizer. Não basta ler o poema: é preciso escutá-lo, é preciso senti-lo. Vem ao encontro dessa ideia a posição de João Felipe Gremski a respeito da escuta na poética ferraziana:

\begin{abstract}
A escuta acontece a partir de um olhar ativo, que busca captar aquilo que não é dito através do trabalho que faz com as imagens, trabalho este que é parte intrínseca na obra do poeta carioca. É a partir dessa escuta que podemos perceber mais claramente de que maneira um olhar não apenas atenta-se para o entorno, mas o sente, cria um laço com ele - um ressoa no outro - e pode, assim, passar a experiência para a palavra poética. Assim, a escuta na poética de Eucanaã Ferraz é, na verdade, uma sinergia entre olhar e ouvir; o entorno é, ao mesmo tempo, visualizado por esse "eu" e ouvido por ele. ${ }^{4}$
\end{abstract}

É possível, entretanto, ir além do olhar e do ouvir, tal como discutimos anteriormente, para trazer à recepção do texto poético uma sinergia que trate também do tocar, do cheirar, do degustar, do sentir, enfim. Tratando da escuta (agora como ato, substantivo) como tarefa exercida pelo leitor, é possível trazer a experiência do corpo deste como parte integrante da recepção (e, portanto, da escuta sensorial e sinestésica) do poema. Nesse sentido, vale observar o estudo de Alckmar Luiz dos Santos ${ }^{5}$ acerca da experiência do corpo do leitor na literatura, baseada na fenomenologia proposta por Merleau-Ponty. Para o pesquisador, "pensar também está no ato de colocar nosso corpo em situação". Ora, se a projeção daquilo que se lê (e se escuta, para insistir numa relação com a obra de Eucanaã) ocorre na formulação imagética puramente imaginativa na mente do

\footnotetext{
${ }^{4}$ Ibidem, p. 156.

${ }^{5}$ Alckmar Luiz dos Santos, Algumas questões sobre corpo e literatura, 2016.

${ }^{6}$ Ibidem, p. 294.
} 
leitor - a partir da mobilização de algum fator externo ${ }^{7}$ - não é preciso ir muito longe para relacionar imediatamente essa imaginação ao pensamento; e, por conseguinte, a sensação do corpo à provocação do texto poético (agente mobilizador da imaginação).

Dado que o corpo se divide entre as instâncias do fenomenal e da matéria, Santos afirma que as sensações podem transitar entre a imanência e a transcendência, por meio de "uma via privilegiada de acesso a tudo que se localiza na esfera do universal"8. Essa via permite que as observações sensoriais que temos como seres humanos não se limitem ao ato físico, mas transcendam a experiência do corpo na direção de uma experiência mais fenomenológica, relacionada aos sentimentos inexprimíveis - que, paradoxalmente, só a poesia (e a própria literatura) consegue expressar. Dessa forma,

podemos dizer que essa experiência corpórea, sob certos aspectos, também se dá no âmbito literário. Também nela, imprimimos sentidos a elementos parciais e precários que vamos atravessando, mas esses sentidos apontam todos para uma generalidade que é, ao mesmo tempo, nunca alcançada e já presente de forma indireta. [...] A expressão literária se constrói apontando para linhas de sentido, para imagens e para ideias que configuram um horizonte longínquo e assimptótico, nunca atingido diretamente, mas sempre influenciando cada elemento imediato que vamos percorrendo com a leitura [...]. ${ }^{9}$

Os significados que essa expressão provocará em nossas percepções corporais (logo, sinestésicas) dependem, também, da bagagem individual que temos como leitores, em experiências anteriores de outras percepções imanentes e simultaneamente transcendentes. Se dedicar-se a ler é lançar-se ao contato com um outro, um desconhecido, mesmo que esse outro desconhecido exista somente no campo da imaginação, é válido concordar que é ele quem "nos faz sentir a iminência de totalidade que subjaz às outras existências" ${ }^{\prime 10}$. A abertura a esse outro é que vai condicionar a recepção sensorial da obra literária, permitindo um contato com outras existências que ressignifique nossas relações com o mundo

\footnotetext{
${ }^{7}$ Cf. Wolfgang Iser, O fictício e o imaginário: perspectivas de uma antropologia literária, 1996.

${ }^{8}$ Alckmar Luiz dos Santos, Op. Cit., 2016, p. 295.

${ }^{9}$ Alckmar Luiz dos Santos, Loc. Cit.

${ }^{10}$ Ibidem, p. 299.
} 
por meio de novos significados às (e a partir das) percepções corporais, dado que na leitura, de fato, "sempre restará um espaço a ser preenchido por outros olhares, outras considerações"11.

Inter-relacionando os horizontes do leitor e do texto, a nossa presença neste, como leitores (e também vice-versa) implica em "alterar sua organização discursiva, de maneira que ela se retorce e se modifica sob o impulso de uma presença outra"12. Essa alteração de ordem discursiva não ocorre de maneira literal, mas a relação que se estabelece talvez permita compreender que, junto da bagagem individual que possuímos como leitores, também a presença do texto sobre nós e a nossa sobre ele influencia certo tipo de leitura e percepção sensorial. Isso talvez seja suficiente para justificar a leitura que vamos propor, mais adiante, dos poemas de Escuta. Por mais ampla que se proponha a ser esta análise, ainda será preenchida pela experiência de um horizonte de leitor: uma experiência anterior de percepção corporal que se desenvolveu, de certa forma, a partir da leitura daqueles poemas.

Nesses parâmetros, propomos buscar, nos poemas de Eucanaã Ferraz, as imagens, figuras e provocações sinestésicas em relação ao sentimento amoroso ora representado com alegria, ora com tristeza - que podem ser evocadas na leitura e na escuta da poesia. ${ }^{13} \mathrm{O}$ amor, em Escuta, se mostra geralmente fragmentado, com a violência típica das relações interpessoais que pouco se estabelecem e menos ainda se estabilizam no contexto da pós-modernidade. $O$ amor será entrecortado pela morte, pela ausência, pela perda; às vezes viverá, às vezes morrerá, mas, no fundo, será sempre o mesmo. Afinal, como já afirmavam os versos de Drummond, "o amor, seja como for,/ é o amor"14. De orelha a orelha, escutemos - e sintamos - o que a poesia tem a dizer.

\footnotetext{
${ }^{11}$ Ibidem, p. 303.

${ }^{12}$ Ibidem, p. 304.

${ }^{13}$ Embora a ideia possa parecer pretenciosa, o recorte aqui proposto levará em conta uma seleção delimitada de poemas ao longo de toda a obra de Eucanaã, de modo que este ensaio não se estenda em demasia.

${ }^{14}$ Carlos Drummond de Andrade, Antologia poética, 2012. p. 167.
} 


\section{De orelha a orelha}

O amor assume diversas facetas na poesia de Eucanaã Ferraz. Também nas primeiras Orelhas, que abrem o livro, o amor é multifacetado, embora esses poemas tratem mais de dar o tom da poética que recobrirá a obra. Marcado pela pontuação breve e sem vírgulas que deem fôlego ao que diz o eu poético (notada pela repetição do ponto e vírgula e por, apenas, dois pontos finais), o ritmo do primeiro poema, intitulado 1 , será frenético, quase violento; como que revelando o desespero desse eu em se fazer ouvir, em fazer escutar as suas certezas:

Estão certas todas as canções banais letras convencionais seus corações como são de praxe; estão certos os poemas enfáticos inchados de artifícios à luz óbvia da luz ou de estúpidos crepúsculos; os sonetos mal alinhavados toscos estão certos bem como as confissões íntimas não lapidadas reles nem polidas; ouçamos o que dizem sobre qualquer coisa; dizem não vai dar certo; repetem; e se o verso é trivial é o mais sagaz quanto mais pueril mais seguro quanto mais frouxo mais sólido quanto mais rasteiro mais a toda prova e quanto mais barato e quanto mais prolixo o alexandrino mais legítimo; as formas desdentadas vêm do fundo; as odes indigestas dizem tudo; o verso oco não traz menos que a verdade nua e ponto. Estão certos os romances de aeroporto; a quem busca um modelo procure o estúpido; se deseja uma estrela de primeira grandeza escolha o simplório; é o que digo não busque senão na aberração a sinceridade e no disparate a franqueza; prêmios literários não passam de hipocrisia; estiveram desde sempre certos os erros de tipografia; o contrassenso deve ser mandamento 


\begin{abstract}
de quem precisa disfarçar o mal-estar após mostrá-lo
sem pudor; sim a saudade arde exatamente como

nos roteiros dos filmes mas só as fitas mais chinfrins

e com fins infelizes não mistificam e dizem de antemão

o que seremos: redundância errância perfeição. ${ }^{15}$
\end{abstract}

A repetição da certeza é a primeira marca deste poema: estão certas as canções banais, os poemas enfáticos, os sonetos mal alinhavados, os romances de aeroporto. Embora a todos os substantivos estejam atrelados adjetivos pejorativos, o eu poético sai em defesa dessas criações artísticas: "ouçamos o que dizem/ sobre qualquer coisa". A resposta, no entanto, já é anunciada: "dizem não vai dar certo; repetem". A posição do eu poético vai na direção de defender a poesia mesmo quando o final é infeliz, mesmo quando o verso é, na verdade, um vazio, posto que "o verso oco não traz menos que a verdade/ nua e ponto". A força deste ponto é de grande importância também ao ritmo, pois parece ser o primeiro ponto, após longas orações e em meio à regularidade de longos versos, em que ao leitor é permitida uma pausa para respirar. É preciso tomar fôlego. Entre os aconselhamentos e constatações que vão da aberração e da hipocrisia à falta de pudor, o eu poético é enfático ao afirmar: a saudade, sentimento caro ao amor e por que não - comum aos corações das "canções banais, letras convencionais", somente ardendo como nos filmes de segunda categoria será capaz de revelar o que caracteriza, o que constitui as identidades dessa tríade em torno do poema ele, eu poético, poeta e poema: "redundância errância perfeição". Pela redundância que se reflete na repetição ora de temas já muito discutidos em toda a poesia do mundo (como o amor), ora nas repetições do próprio poema, o tom de anúncio na abertura do livro é certeiro ao provocar a liberdade do verso; coloca, ainda, como objeto direto do verbo ser (seremos), outros dois substantivos que paradoxalmente se complementam: errância e perfeição.

\footnotetext{
${ }^{15}$ Eucanaã Ferraz, Op. Cit., 2015, p. 13.
} 
Defendido o direito de fazer poesia, o tema do amor é apresentado na segunda orelha em um jogo duplo com a metalinguagem, no qual também esta se estende a um duplo, dado que língua é o substantivo de onde deriva linguagem; ato contínuo, de onde vem a metalinguagem. O sentido do poema, no entanto, vai além da linguagem enquanto forma linguística e ferramenta para produzir versos: retoma o substantivo na sua mais remota ancestralidade para o movimento da própria língua.

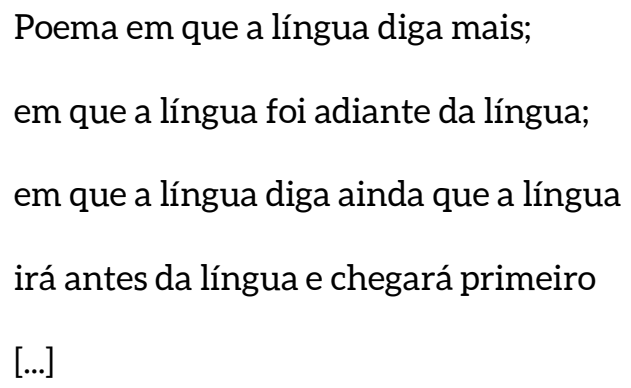

Esse movimento de busca é cortado pela chegada

$$
\begin{aligned}
& \text { a um céu sem nuvem sem anjo sem pássaro } \\
& \text { sem signos do zodíaco porque não há estrelas } \\
& \text { na abóbada do papel em branco entre dentes } \\
& \text { [...] }
\end{aligned}
$$

A marca da metalinguagem poética é perceptível aqui, quando aparece a imagem do papel em branco, superfície onde se deposita o poema. Entretanto, com os versos seguintes, o movimento da língua e mesmo a figura do papel podem metaforizar outro elemento:

$$
\begin{aligned}
& \text { como pedras desenhando um país deserto } \\
& \text { em que a língua já não diga a língua } \\
& \text { que a anule numa espécie de fruto sem árvore } \\
& \text { ou semente; língua inexplicavelmente } \\
& \text { que para facilitar chamemos beijo. }{ }^{16}
\end{aligned}
$$

\footnotetext{
${ }^{16}$ Ibidem, p. 14.
} 
Esse elemento, como anunciado, é o próprio beijo. O movimento da língua é talvez inexplicável; tanto que, nos primeiros versos, propõe um fluxo de movimento intenso e repetitivo. Porém, se levarmos em conta que a falta de explicação é resumida a um beijo, e considerando que, quando os amantes se beijam e envolvem suas línguas o movimento destas é sempre anterior, em direção ao outro, toda a imagem do poema se transforma a partir da palavra beijo, sendo todo ele, talvez, a explicação de um beijo de amantes.

Completando a ideia do poema que mais se relaciona com as sensações em detrimento da metalinguagem, o céu sem nuvens, sem estrelas e entre dentes pode bem representar o próprio céu da boca, e as sensações a ela relacionadas podem evocar tanto o tato quanto o paladar. Para isso, basta que o leitor saiba o gosto de um beijo, o movimento da língua e do toque dos lábios. O beijo, para o leitor, obviamente não será literal, mas provocará sua participação corporal na leitura do poema. O beijo, físico e literal, inicia com o toque: dos lábios, das línguas. Contudo, retomando o poema como expressão metalinguística, o beijo pode, ainda, estar relacionado ao selo da tinta sobre o papel em branco, momento sublime em que a poesia ("espécie de fruto sem árvore/ ou semente") irrompe. Eis a experiência corpórea que se realiza na superfície do texto de literatura, como observa Santos em citação mencionada há pouco. ${ }^{17}$

Passando pela camada externa do órgão de escuta, chegamos ao conteúdo que os ouvidos protegem - este, localizado no miolo de poemas do livro que se divide em três partes. A primeira delas, sob o nome Ruim, é a única cujos títulos dos poemas são compostos por mais de uma palavra, construídos a partir de orações ou expressões geralmente constantes nos respectivos poemas. Com ritmo volúvel e temática bastante diversa, os poemas estão mais centrados na guerra, na perda, na introspecção do eu poético; geralmente distantes do amor. Este aparece com clareza pela primeira vez em Foi-se a vontade de ir ao Egito, ${ }^{18}$ poema em que o eu poético narra as transformações de um homem ao seguir o conselho

\footnotetext{
${ }^{17}$ Alckmar Luiz dos Santos, Op. Cit., p. 295.

${ }^{18}$ Eucanaã Ferraz, Op. Cit., 2015, p. 31.
} 
de todos e parar de fumar. Amar, aqui, assume a face do amor próprio - ora voltado ao todo da sociedade, ora dependente dela - e encontra na analogia bíblica a ironia da desilusão amorosa. Parou de fumar, e

\section{$[\ldots]$}

Com isso parou também de amar o próximo como a si mesmo e passou a duvidar de que um dia tenha amado a si mesmo.

O parar de fumar pode ser o caminho para a ruína dessa persona do poema que, seguindo o aconselhamento de todos ("Todos foram unânimes: precisava parar de fumar", primeiro verso do poema), deixa de lado os prazeres que o vício lhe garantia. A figura desse todos, termo que não designa exatamente um quem objetivo, pode ser dedicada à pura inferência imaginativa do leitor; o foco, no entanto, recai muito mais sobre o resultado da ação praticada pelo suposto coletivo. Em detrimento do conselho, o personagem ainda perde os amigos, perde as piadas, e perde "[...] o prazer físico e místico de olhar/ as nuvens pela janela do avião como anéis/ de fumaça [...]". A figura metafórica da fumaça, que aparece explícita a partir deste verso, talvez evoque a sensação olfativa no leitor que tendo fumado ou não - poderá imaginar-se imerso em uma nuvem de fumaça de cigarro (ou outra espécie de fumo, já que não fica evidente no poema tratar-se de cigarro). A totalidade de sensações relacionadas ao abandono do vício, no entanto, talvez só possa ser compreendida pelo leitor que já tenha fumado ou que seja fumante. Sensações estas de aprisionamento e sufocamento - contidas nos versos finais da obra - suficientes para selar o distanciamento do amor por si mesmo, do amor ao próximo referenciado no início do poema:

\section{$[\ldots]$}

Mas, sobretudo, passou a sonhar insistentemente com rãs que invadem seus pulmões sua casa. 
O tema do amor aparece também no belíssimo poema Na curva deste minuto, ${ }^{19} \mathrm{em}$ que o eu lírico assume, em primeira pessoa, a desilusão amorosa. $\mathrm{O}$ poema não trata exatamente de amor, posto que suas figuras remetem por vezes à guerra ("Há mortos no chão da praça./ Centenas. Quem os recolhe?/ A vida não nos devolve/ e há mísseis no céu de maio"). Por outro lado, a repetição anafórica do verso "Chorai, fadistas, chorai" evoca o drama de amor, o drama degradante da figura do eu poético, semelhante aos fados portugueses - cantados, obviamente, por aqueles a quem o eu lírico clama. De fato, o verso propõe uma intertextualidade com o Fado da Severa, da autoria de Sousa do Casacão em 1848 - no contexto em que o verso está relacionado à morte de Maria Severa Onofriana, fadista conhecida no início do século XIX que faleceu muito jovem (aos 26 anos) e é reconhecida iconicamente como a primeira fadista:

\section{Chorai, fadistas, chorai \\ Que a Severa já morreu: \\ E fadista como ela \\ Nunca no mundo apar'ceu. ${ }^{20}$}

De volta ao poema, a perda do eu poético não está relacionada necessariamente - à morte da amada, mas à desilusão amorosa: afinal, como se verá, o insucesso reside na não correspondência deste amor.

$$
\begin{aligned}
& \text { [...] } \\
& \text { Um rosto rápido escapa } \\
& \text { na curva deste minuto } \\
& \text { e nunca mais retornamos } \\
& \text { à casa dos nossos dias. } \\
& \text { É preciso que eu resista, } \\
& \text { não diga chorai, fadistas, }
\end{aligned}
$$

\footnotetext{
${ }^{19}$ Ibidem, p. 32-33.

${ }^{20}$ Museu do Fado, Severa, 2017.
} 
o sucesso já perdido

de um amor - que não me ama.

Fadistas, secai os olhos.

A figuração sinestésica, neste poema, é mais subjetiva, mas talvez possa ser relacionada à visão do rosto que "escapa/ na curva deste minuto". É como se, num instante, a figura deste rosto (que pode ser, ainda, o da amada) lhe passasse, e fosse suficiente para despertá-lo à realidade, para fazê-lo respirar (posto que, no ritmo do poema, as pausas são ainda demarcadas pela frequência de pontos finais e vírgulas) e resistir, deixando de lado o drama amoroso, degradante em relação à sua percepção sobre as coisas do mundo. Este novo suspiro provoca a certeza da resistência, de modo que a ordem do sujeito lírico inverte a ação em relação aos cantores de fado: "Fadistas, secai os olhos".

Outros poemas vão tratar, ainda, da desilusão amorosa, revelando que a resistência proposta em Na curva deste minuto se restringe a tal poema. É o caso, por exemplo, de E desenha na memória, ${ }^{21}$ cujo eu lírico trata de uma mulher cansada da vida no trabalho, que "não suporta mais a hipocrisia a burrice a pose o café ruim". Seu recurso de fuga é a memória, a projeção imaginativa: "Fecha os olhos/ e desenha na memória um jardim feroz". Ainda assim, o questionamento em torno do amor (ou da falta dele) é recorrente, como se nota no verso final: "Quando virá o tempo do amor feito só de domingos?".

Entretanto, talvez nenhum dos poemas de Ruim sintetize a decadência do humano, a dependência da opinião alheia, a desilusão do amor pelo outro e a perda do amor próprio tão bem quanto O Ruby Passion:

Senta-se em frente à televisão.

Ou melhor, antes disso

vai ao cabeleireiro cobre as raízes brancas

${ }^{21}$ Eucanaã Ferraz, Op. Cit., 2015, p. 35. 
com o louro intenso número 8

e ainda pede ao Ricardo que lhe apare as pontas ressecadas.

Depois pega da bolsa o Ruby Passion passa-o nos lábios três quatro vezes

cuidadosamente. Em casa, senta-se em frente à televisão liga

naquele programa que dá informações valiosas de beleza e saúde fáceis de inserir no dia a dia e seguindo as orientações da mulher que explica tudo com voz calma põe a coluna ereta faz inspirações e expirações profundas enquanto aperta com a mão direita o revólver que o marido esconde na gaveta pequena da cômoda. Você não sabe segurar uma arma e pensa que talvez não dê certo mas eu não sou uma boba você 
diz a si mesma é preciso tentar eu

sou uma mulher

tem que dar certo diz baixinho

encostando o cano no lado

do coração que bate alto

acelerado posso ouvir daqui. ${ }^{22}$

O ritmo, marcado pela ausência de vírgulas - principalmente a partir do segundo verso da quinta estrofe - e pela presença, dali em diante, de apenas um ponto final no meio do poema - primeiro verso da décima estrofe -, é compassado pela métrica quase regular entre os versos. Estes lembram, com velocidade, movimento e as pausas entre as estrofes, os batimentos do coração. Nesse contexto, a sensação de ansiedade pela ação que se desenvolve é possível de ser sentida quando ouvido, quando escutado o poema. A sinestesia possível a partir dessa experiência de leitura remete ao pensamento de Santos em relação às linhas de sentido. Na visão do autor, estas são construídas a partir da expressão literária, em função de que as ideias e imagens estabelecidas na mente do leitor são influenciadas pelos elementos que, imediata e simultaneamente - como as pausas e a pontuação - aparecem no percurso da leitura. ${ }^{23}$

O Ruby Passion trata de uma mulher já madura, talvez idosa, dadas as "raízes brancas", às quais vai ao cabeleireiro cobrir com "louro intenso número 8". Arruma-se, passa batom vermelho nos lábios e, ao chegar a casa, entrega-se à futilidade: liga a TV no programa em que são dadas dicas fáceis de beleza e saúde. Talvez ela tenha assistido a esse programa em outras ocasiões; mas sua atenção, nesse momento, está voltada a outra ação, presente no seu mundo real: o suicídio.

\footnotetext{
22 Ibidem, p. 51-52.

${ }^{23}$ Alckmar Luiz dos Santos, Op. Cit., 2016, p. 295.
} 
A preparação, intensa, é preenchida pela respiração profunda enquanto ela segura o revólver do marido. Será ele o motivo? O discurso indireto coloca na voz do eu lírico o diálogo solitário da mulher: "eu não sou uma boba [...]/ é preciso tentar", e se encerra com a única certeza trazida ao poema, justamente por meio do seu verso mais curto: "eu sou uma mulher". Certeza, porém, incapaz de salvarlhe a vida, mas suficiente para cobrar-lhe força para executar a ação que pode matá-la. A relação do eu lírico é mais próxima da ação da mulher na última estrofe, quando revela ser capaz de ouvir, à distância, o coração da mulher. Não sabemos, como leitores, que distância é essa; mas somos capazes de acompanhar a ação, a respiração e talvez até mesmo sentir (ou também ouvir) a aceleração do coração. Se ela consuma ou não a própria morte, a resposta fica a cargo da imaginação do leitor, que é possivelmente tensionado a uma resposta afirmativa. A palavra amor não aparece nos versos, mas como um poema como esse não trata da falta de amor?

Quando relacionado ao poema seguinte, o último da seção Ruim, essa tensão fica ainda mais evidente e certeira: Nessas horas num momento ${ }^{24}$ é outro poema intenso, em estrofe única, de ritmo acelerado e sem marca alguma de pontuação entre os versos. Revelando a ansiedade do eu poético em relação à situação de morte, parece questionar: afinal, o que dizer, o que fazer na hora da perda? Retomando falas comuns e populares que dizemos em velórios e funerais, a fuga é a ação mais imediata, ironicamente marcada no último verso:

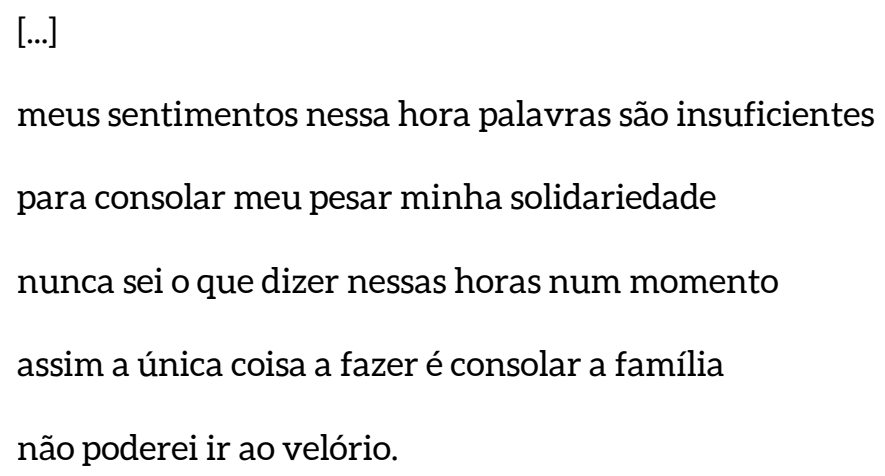

${ }^{24}$ Eucanaã Ferraz, Op. Cit., 2015, p. 53. 
A seção seguinte, chamada Alegria, traz outras faces do amor, já não necessariamente relacionados à perda, mas à superação e à autoconfiança a partir dele. Em Fábula, ${ }^{25}$ o eu poético volta a tratar de uma mulher provavelmente idosa, descrita por meio das "raízes brancas do cabelo ralo" que "brilham em arco sob o acaju". Apresentada na quarta estrofe como dona Baratinha, a grande questão vai além da personagem da cantiga popular e da fábula, às quais o poema propõe intertextualidade. Na canção, a pergunta feita em relação a ela gira em torno de "Quem quer casar com a senhora Baratinha/ Que tem fita no cabelo e dinheiro na caixinha/É carinhosa e quem com ela quiser se casar/ Terá doces todo dia, no almoço e no jantar"26. O poema ultrapassa a representação dos problemas de dona Baratinha: apesar da sua fortuna, "quem se disporia a erguer palácios [...]/ com o mármore azul de suas varizes?// A ninguém apetece dormir sobre o tapete amarrotado de seu colo". O eu poético responde à pergunta da canção: "Ninguém quer casar com dona Baratinha".

Contudo, diferente da mulher suicida de O Ruby Passion, a dona Baratinha do poema é uma mulher à frente, autônoma, decidida na busca pelo amor:

Mas ela quer amor.

Ela quer amar.

Hoje, por exemplo, acordou bem e se sentiu outra

vez jovem e bela entre bibelôs girando na penteadeira.

O poema também revela a origem de sua fortuna: a pensão do falecido marido. Além de sentir-se bem, a grande marca da independência de dona Baratinha em busca do amor está no investimento que dá a esse dinheiro; se o amor não vem por si, ela pode comprá-lo:

Dona Baratinha só quer um pouco de amor.

\footnotetext{
${ }^{25}$ Ibidem, p. 61.

${ }^{26}$ Braguinha, A história da baratinha, 2017.
} 
E seria muito triste se não pudesse comprar um pouco disso.

O amor comprado por ela está provavelmente mais relacionado ao sexo do que ao sentimento amoroso ou à paixão, enfim. As sensações provocadas por esse sentimento, no entanto, a partir da posição de dona Baratinha como alguém que já não goza da juventude, dotam-na da independência e da autoaceitação suficientes para carregar consigo aquilo que a mulher de $O$ Ruby Passion não possuía: a consolidação do amor por si mesma. Embora também integre esse mundo contemporâneo fragmentado, de relações passageiras e pouco sólidas, talvez seja dona Baratinha quem melhor se adapte ao espaço-tempo e dele consiga extrair algum benefício (ou adaptar-se pela sobrevivência, mas isso seria pauta para outra discussão, mais longa, que não cabe neste ensaio).

O amor volta à voz pessoal do eu poético em Simples, ${ }^{27}$ poema que melhor caracteriza uma declaração terna dedicada ao ser amado. Composto em bloco único, o ritmo do poema é mais lento, espaçado pelas diversas vírgulas, pontos finais e enjambements constantes ao longo do texto. Assim como os outros, é um poema para ser escutado; para que suas metáforas sejam assimiladas senão racionalmente, pelo menos por via do sentimento, da sensação. Os primeiros versos são enfáticos: "Se você não sai da minha cabeça,/ minha cabeça é seu apartamento"; como se a própria cabeça, lugar onde se abrigam os pensamentos e os motores das sensações e sentimentos (assim como o próprio sistema nervoso central, a memória, as funções do cérebro, enfim), fosse preenchida pela presença de quem se ama. O eu poético afirma: "Devia pensar/ noutras coisas", mas admite: "Não tenho cabeça para outro assunto./ [...] Perdi a cabeça e já não há remédio". O discurso é direcionado objetivamente ao ser amado:

\footnotetext{
Você me subiu à cabeça - forças

belezas alegrias me pertencem.

[...] E se giro

por aí com a cabeça no ar
}

${ }^{27}$ Eucanaã Ferraz, Op. Cit., 2015, p. 76-77. 
carregando você, minha cabeça

é um balão bailando então. Sim, daqui

a cordilheira dos Andes é nítida.

O estado de paixão é completado pelo sentimento de posse em relação ao que é belo, ao que é alegre - coisas naturalmente vinculadas à realização do amor. As assonâncias nasais no penúltimo verso destacado comprovam a rima - quase boba - oriunda desse baile de sonhos, metáforas e sensações múltiplas que caracterizam o sentimento amoroso. Mais do que isso: a paixão é capaz de elevar o eu poético a grandes altitudes, fazendo-o grande, flutuante e leve - sensação de leveza que se reflete ainda nos versos finais:

\footnotetext{
Escute, escreverei uma coisa

tão simples assim: você é meu sol.

Porque você me deixa com a cabeça

quente. E sem juízo, imaginando.
}

O uso do verbo escute não aparece em vão: mais do que pedir que o ser amado o ouça, a relação com a escuta do título (e do corpo) da obra poética não pode ser deixada de lado. Vale repetir: não basta ler o poema, é preciso escutá-lo. Assim como o amor, é preciso também senti-lo. Tentando simplificar as descrições, o eu poético compara o ser amado ao sol - o Astro Rei, o centro da galáxia. Sem o sol, não há vida sobre a terra, não há calor que regule os ventos ou fenômenos da natureza. É preciso que haja calor; é preciso que haja amor mesmo que seja sem muito juízo.

As Memórias póstumas, última seção de poemas antes das Orelhas finais, tratam de um amor póstumo ou da morte do amor, trazendo à superfície dos versos o lamento do amor perdido; já não necessariamente a falta dele (como acontecia em Ruim) ou a alegria de sua plenitude (como acontecia na seção intermediária). O ritmo dos poemas desta seção propõe uma mescla entre aquilo que já se via anteriormente, oscilando dos versos velozes aos mais lentos, às vezes no corpo do próprio texto poético. Os poemas também são mais breves, embora 
não percam nada em profundidade e sensação em relação aos anteriores - fator refletido inclusive nos títulos, geralmente construídos por monossílabos átonos. Essa não-tonicidade, no entanto, não coaduna com o conteúdo dos poemas. Em Eis, ${ }^{28}$ poema de abertura, o tom é acentuado, feroz:

$$
\begin{aligned}
& \text { Parte considerável dos casos de amor } \\
& \text { vividos ao longo e ao estreito destes séculos } \\
& \text { permanece submersa. Destroços } \\
& \text { podem ser encontrados aqui nos intestinos. } \\
& \text { Mas romancistas cineastas estudantes editores } \\
& \text { todos estão mais interessados em explorações } \\
& \text { de caça-níqueis ao tesouro. Poemas } \\
& \text { porém continuam inventando sítios } \\
& \text { arqueológicos sob a água desses dias de merda. }
\end{aligned}
$$

Obviamente, a submersão a que se refere o eu poético não é literal; os casos de amor de toda a humanidade, "ao longo e ao estreito" da história é que afundam-se nela mesma e, talvez, no próprio esquecimento. Se antes o eu poético flutuava diante - e a partir - do amor, agora o mesmo sentimento é motivo de peso e pesar, de modo que só se encontram, na atualidade, os seus destroços. Localizar estes últimos "nos intestinos" é figurar a contemporaneidade fragmentária em suas relações utilizando de cruel metáfora. Não obstante, o amor só é objeto de interesse, na contemporaneidade, para quem busca algum tipo de lucro, de vantagem - como é o caso de romancistas, cineastas, estudantes. Somente o poeta é apto para ver o amor em seu estado real: também ele submerso, é o único capaz de evocar, no poema, e dar vida às histórias de amor; somente ele, em meio a esses "dias de merda".

A submersão, porém, também evoca o naufrágio, metáfora pungente para a desilusão amorosa. Afinal, o que mais pode provocar a sensação de um poeta a

\footnotetext{
${ }^{28}$ Ibidem, p. 99-100.
} 
desbravar o amor, quando este não está tratando de dedicar galanteios? O oposto do happy ending, obviamente, é o próprio naufrágio - do amor ou do eu poético em meio aos próprios sentimentos. A voz declara, como que conversando com um médico:

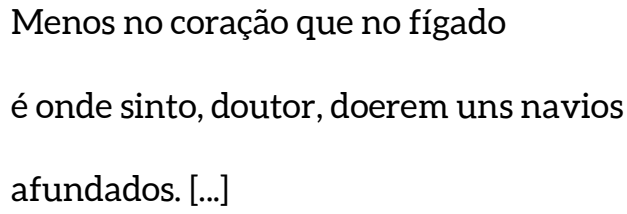

É por meio dessa constatação que o poeta vai dedicar os poemas à "memória de todos os amantes/ mortos em combate", intermediado pelo eu poético neste poema - que abre a última seção da Escuta - como se o amor ou a sua conquista mobilizasse um combate: entre seres, entre sentimentos, entre sensações. O trecho ainda revela que o próprio eu lírico é um sobrevivente, dado que é no fundo da submersão (no âmago de si, de seus sentimentos?) que ele constata a presença de amores; os quais, naufragados, o foram entre suas costelas. A interpretação da metáfora não precisa ir muito longe: se ao coração são atribuídos os sentimentos, entre eles principalmente o amor, que outro órgão do ser humano fica localizado entre as costelas?

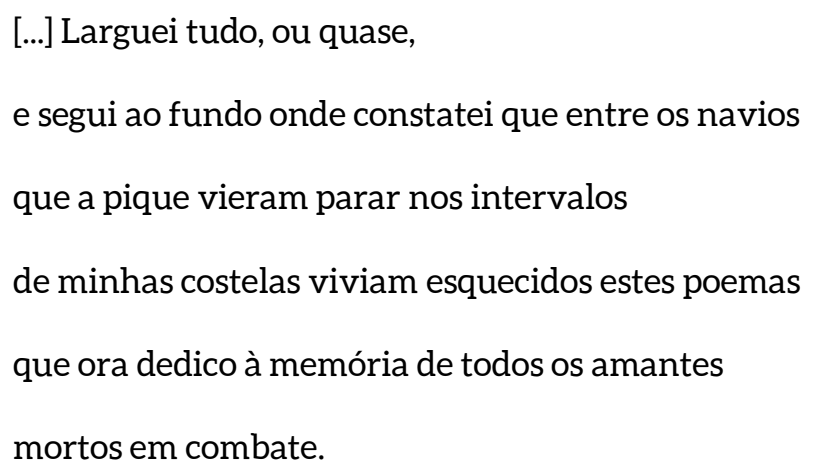

Naufragado em desilusão, será comum ao eu poético insistir em revelar a falta de correspondência entre os amantes, atestando o óbito do próprio amor. Revelação que, às vezes, se estende até mesmo à ausência deste, posto que - como visto no poema anterior - o amor permanece objeto de exploração, não de 
sensação. Um desencontro pode ser verificado em $\mathrm{Se}^{29}$ poema de versos breves com ritmo cortado pelos enjambements (tão presentes na obra de Eucanaã) e pelos espaços entre os dísticos:

Finjo que não percebo

faço que não há falta.

Simplesmente não sabe dizer

Amor.

$[\ldots]$

Digo e peço que repita

faço como quem guia uma criança

que se alfabetiza, amor,

repita,

ator, diz;

não, digo, amor;

insisto, amor;

interruptor, diz;

amor, digo, diga comigo,

diz intempérie.

$[\ldots]$

${ }^{29}$ Ibidem, p. 103 a 105. 
peço, digo assim não posso,

você não quer, acuso;

e vejo - você está de costas

ou talvez tenha saído - arder

entre nós a transparência mortal

da palavra não.

O discurso traz ao poema, pela primeira vez, as respostas ao diálogo entre o eu poético e o ser amado, mesmo que tais respostas sejam apresentadas por meio da voz do primeiro. Ainda assim, o diálogo reflete bem o desencontro com um amor que não ama, que não corresponde. Não saber dizer a palavra amor é a metáfora para não saber senti-lo, pelo menos não em relação ao eu que lhe cobra amor. Tanto o é que, entre as respostas cruzadas (que, embora distintas, se aproximam pela rima da sílaba final or), surge uma "intempérie": um mau tempo, uma tempestade nessa relação. Pressionado, o interlocutor do eu lírico se distancia, deixando à sua visão - e sua sensação - a paradoxal transparência "da palavra não". Nenhuma outra palavra poderia selar de maneira mais trágica, mais "mortal", esse distanciamento, que o pronome absoluto de negação empregado sem rodeios.

Desolado, o eu poético suplicará, no poema Por, ${ }^{30}$ que o mesmo amor (novamente grifado em itálico) seja abandonado. A súplica se revela pelos verbos no modo imperativo, sendo justificada pelo eu poético com base nas experiências sensoriais que $\mathrm{o}$ amor lhe provocara:

Tirem-me daqui a palavra amor.

Pingando sangue e açúcar ela pesa

e suja o que antes era a claridade.

${ }^{30}$ Ibidem, p. 109. 


\begin{abstract}
Tiremos de entre nós essa palavra
pois lembro que antes de a pronunciarmos

os nosso dias eram mais suaves
\end{abstract}

os nossos dias eram só a pele.

Por isso afirmo que é preciso urgente

lançar ao lixo sem nenhuma pena

tal diamante $[. .$.

Mesmo que seja fruto de um sentimento doce, mesmo que seja um diamante, o amor machuca e é machucado (posto que "pinga sangue"), poluindo de escuridão e dor a vida de quem tinha a pele de seus dias mais suaves. Antes saudável, agora machucada, a pele não resiste à palavra amor. Para que possa se recuperar, o eu lírico clama com urgência: lancem ao lixo esse amor, esse diamante, "porque ele arde em nossa/ língua e dissipa nosso lábio cada/ vez que o dizemos. Enfim, esqueçamos". É preciso esquecer o amor; deixar de lado essa dor que fere, que arde, que corta a pele e o lábio e que machuca o tato. Perdido e cansado, o final do texto assume a forma de uma última súplica, como se o eu poético quisesse esquecer o amor e abandoná-lo ao pé do poema. No entanto, como expresso no poema Des, ${ }^{31}$ não basta esquecê-lo, porque a memória é reincidente e persistente; daí que o eu poético afirme:

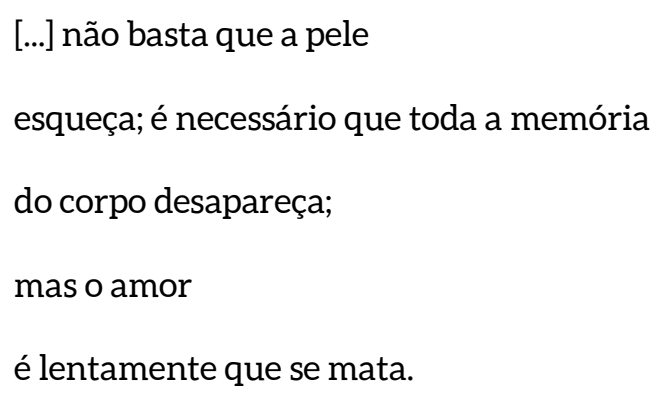

${ }^{31}$ Ibidem, p. 114. 
Morto o amor, o que restará à poesia? Se falta o primeiro, falta também a poesia, dado que ele configura força motriz para prosa e verso em histórias a perder de vista. Para corroborá-lo, basta uma olhada rápida no caminho que viemos traçando entre os poemas deste ensaio - exemplo suficiente para não precisar ir muito longe. $O$ eu poético é ciente dessa situação: no poema $X,{ }^{32}$ o discurso assume tom profético ao anunciar que a falta de amor é causadora da falta de poesia, o que se revela principalmente nos dois últimos versos:

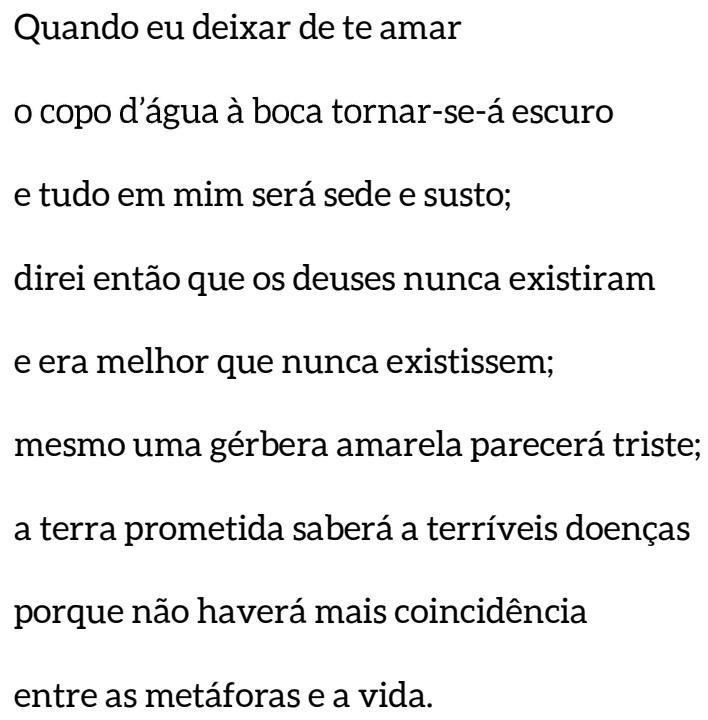

É o próprio poema que aproxima as metáforas da vida, que aproxima a literatura das sensações e vice-versa, que coloca o corpo na situação do texto literário. ${ }^{33}$ Além disso, é ele (o poema) que condensa a crença nas divindades e distancia a vida do puro ceticismo racionalista; é ele que mata a sede de amor e claridade, que dá verdadeira alegria aos mínimos detalhes da paisagem. $\mathrm{O}$ amor, aqui, não se refere apenas ao ser amado, mas também à própria poesia: deixando de amar, o eu poético abandona as coincidências figurativas e se entrega às trevas profundas que caracterizam a falta de amor. Resultante desse possível efeito, as sensações já não podem mais ser tão aprazíveis ou facilmente provocadas pela escuta dos versos; posto que é somente por via das metáforas - e, repita-se, do poema - que as sensações são possíveis à leitura, à escuta, aos sentidos, enfim.

\footnotetext{
${ }^{32}$ Ibidem, p. 115.

${ }^{33}$ Alckmar Luiz dos Santos, Op. Cit., 2016, p. 294.
} 
Ciente da necessidade da poesia, Escuta chega às orelhas finais com uma declaração amorosa do eu poético (desta vez - por que não? - do próprio poeta) em relação ao momento sublime em que nasce o poema, como se observa em 3 :

\begin{abstract}
Amo a margem esquerda onde irrompe o poema
onde principia esse espaço que semelha um pátio onde o vazio recua para que a voz gráfica se faça.
\end{abstract}

[...]

\begin{abstract}
Mas antes que o poema exista a margem esquerda
é apenas um ramo invisível - galho provável

na árvore que imaginamos e que só vive
\end{abstract}

\begin{abstract}
quando um verso exausto de também não ser
se apoia na parede reta nas encostas ásperas

da página que espera. ${ }^{34}$
\end{abstract}

A "margem esquerda" figura a superfície em branco do papel que espera a tinta para receber o "verso exausto de também não ser", de ainda não existir. A realização dessa existência, materializada na voz que se transcreve em código escrito, transforma a página e o conteúdo em ser vivo, "contra o qual o mundo se espedaça e o mundo/ recomeça para morrer algumas águas adiante". Esse encontro fortuito entre o papel e o poema remete à segunda orelha, na qual o beijo - toque dos lábios e das línguas dos amantes - também simbolizava o toque da tinta sobre o papel branco. Momento realmente sublime este em que a poesia nasce, irrompe "da página que espera" e se lança a ser ouvida, escutada, sentida, amada. Ainda que o amor trilhe percursos errantes, ou que seja cortado por intempéries e por versos duros, às vezes cruéis; mesmo que este, em suas múltiplas faces, porventura morra ou se desiluda. Ainda assim, a orelha 4 fecha o livro com um último pedido do eu poético: é preciso perdoar o poema, é preciso

\footnotetext{
${ }^{34}$ Eucanaã Ferraz, Op. Cit., 2015, p. 125.
} 
dizê-lo, é preciso ouvi-lo. Esse pedido vem em um movimento de "redundância" (como no verso final da orelha de abertura, 1) que muito se aproxima da "perfeição":

\author{
Eu te digo que é preciso não morrer no poema; \\ que é preciso amar e não parar o pulso de amar \\ no poema; [...] \\ Eu te digo que é preciso aceitar o verso ruim \\ dar a outra face ao silêncio do poema no poema \\ e ver partir sem pena os verbos que sagrados \\ só se digam sob o teto de jamais os pronunciarmos; \\ é preciso deixar que no poema venha quebrar \\ a maré rasa das palavras ultrajadas repetidas \\ repisadas nos jornais nos livros nos mercados \\ apanhadas com o coração na boca e no engano \\ dos sentidos e do espírito entre os dentes; palavras \\ tantas vezes obras que pobres não valem a tinta \\ de novamente serem ditas; dizê-las, no poema; \\ eu te digo que é preciso perdoá-las. ${ }^{35}$
}

\title{
3. Palavras finais
}

Falar do amor, daquilo e/ou de quem se ama constitui tarefa árdua. Faltando palavras, repetimos eu-te-amos a torto e a direito, até mesmo quando o risco desse amor ser passageiro, superficial e fragmentário (como são a maioria das relações contemporâneas) é sabido de antemão. Faltam, no entanto, palavras. Faltam verbos, faltam adjetivos, faltam substantivos que deem conta de

\footnotetext{
${ }^{35}$ Ibidem, p. 126.
} 
expressar esse sentimento. Falta domínio sobre a linguagem que muitas vezes nos domina. Quem, contudo, melhor poderia fazê-lo do que o poeta?

Maria de Lourdes Baldan já afirmava, em 2011, que na poesia de Eucanaã Ferraz

a língua se transforma numa espécie de "projetor verbal", que vai transformando em verbo as imagens plásticas e sonoras que sincreticamente capta. E o verbo vai devolvendo em imagem e som, mediatizado pela montagem e direção do poeta, a poesia que se deixa ver/ouvir pelos seus leitores. ${ }^{36}$

Com Escuta, parece que a poesia de Eucanaã dá um passo adiante nessa relação entre imagem e som, provocando a partir dela, como vimos, uma leitura - ou melhor, uma escuta - multissensorial. Guardados entre as Orelhas, os poemas não são apenas escutados ou vistos pela projeção imaginativa: são degustados, são cheirados, são tocados, são sentidos. É nesse contexto, enfim, que o poeta fala do amor, expondo um eu lírico que ora apresenta sensações mais introspectivas (perceptíveis no discurso em primeira pessoa), ora se impessoaliza, falando das sensações de um outro que, como ele, também sente, sofre, chora, toca, ri, sonha, ama. Mesmo quando o amor não trata necessariamente do ser amado, o sentimento é profundamente humano; de modo que sua temática é facilmente entrecortada pela perda, pela morte, pela ausência e pelas paisagens, que compõem o pano de fundo dos poemas. Isso permite que, de toda sorte, o poeta sempre peça para que se escute e se sinta o amor, mesmo que suas palavras sejam ásperas: afinal, é preciso dizê-las, "é preciso perdoá-las". Drummond é que estava certo: o amor, seja como for, é sempre o amor.

${ }^{36}$ Maria de Lourdes Baldan, Algumas considerações sobre a poesia de Eucanaã Ferraz, 2011, p. 13. 


\section{Referências}

ANDRADE, Carlos Drummond de. Antologia poética. São Paulo: Companhia das Letras, 2012.

BALDAN, Maria de Lourdes O. G. Algumas considerações sobre a poesia de Eucanaã Ferraz. Cadernos de Semiótica Aplicada, Araraquara/SP, v. 9, n. 2, p. 114, dez. 2011.

BRAGUINHA. A história da baratinha. Disponível em:

https://www.letras.com.br/braguinha/cantigas-de-a-historia-da-baratinha. Acesso em: 30 ago. 2017.

FERRAZ, Eucanaã. Escuta. São Paulo: Companhia das Letras, 2015.

GREMSKI, João Felipe. Um estudo da obra poética de Eucanaã Ferraz. 2016. 169f. Dissertação (Mestrado em Letras) - Universidade Federal do Paraná, Curitiba. ISER, Wolfgang. O fictício e o imaginário: perspectivas de uma antropologia literária. Rio de Janeiro: EdUERJ, 1996.

MELO, Tarso de. Com Versos Densos, Eucanaã Perturba e Diverte em Escuta. Folha de São Paulo, São Paulo, 2 jul. 2015. Caderno: Ilustrada, p. 3-3. Disponível em: http://www1.folha.uol.com.br/ilustrada/2015/07/1650257-com-versosdensos-eucanaa-perturba-e-diverte-em-escuta.shtml. Acesso em: 25 ago. 2017.

MENDES, André di Bernardi Batista. Vozes do Mundo. Estado de Minas, Belo Horizonte, 13 jun. 2015. Disponível em: https://www.uai.com.br/app/noticia/pensar/2015/06/13/noticiaspensar,168623/vozes-do-mundo.shtml. Acesso em: 25 ago. 2017. 
MUSEU DO FADO. Severa. Disponível em:

http://www.museudofado.pt/personalidades/detalhes.php?id=368. Acesso em: 27 ago. 2017.

SANTOS, Alckmar Luiz dos. Algumas questões sobre corpo e literatura. In:

CECHINEL, André (Org.). O lugar da teoria literária. Florianópolis: Editora UFSC;

Criciúma: EdiUNESC, 2016. p. 293-318.

Referência para citação deste artigo

CYRINO, Lucas. A escuta do amor, de orelha a orelha. Revista PHILIA I Filosofia, Literatura \& Arte, Porto Alegre, volume 1, número 2, p. 364 - 394, outubro de 2019. 